\title{
SUSTAINABLE DEVELOPMENT LAWS IN ETHIOPIA: OPPORTUNITIES AND CHALLENGES OF THEIR IMPLEMENTATION
}

\author{
Teferi Bekele Ayana* \\ Wekgari Dulume Sima**
}

\begin{abstract}
Despite the recognition of sustainable development in different legal documents and laws in Ethiopia, implementation in its fullest sense remains a key challenge. This article examines the place of sustainable development under the Federal Democratic Republic of Ethiopia (FDRE) Constitution and other national environmental laws. It discusses the challenges of promoting sustainable development in Ethiopia by reviewing the existing and relevant literature and assessing legal documents and commitments made by the country. The article recommends the working together of government as well as environmental and investment institutions to make coordinated and coherent efforts to advancing effective implementation of sustainable development and the realization of SDGs in Ethiopia.
\end{abstract}

Keywords: Sustainable Development, Constitution, Environmental Laws, Challenges

DOI: https://dx.doi.org/10.4314/jsdlp.v9i2.3

\section{INTRODUCTION}

Sustainability is an idea that has existed for over two millennia. Sustainability was initially understood in its narrow sense as economic sustainability. This could be observed from the argument in the book

* LL.B, LL.M, Editor-in-Chief of Oromia Law Journal, and Senior Legal Researcher at Oromia Justice Sector Professionals Training and Legal Research Institute. Email: bekele.teferi@yahoo.com

** LL.B, LL.M Candidate, Senior Legal Researcher at Oromia Justice Sector Professionals Training and Legal Research Institute. Email: wekgaridulume@yahoo.com. 
Carlowitz wrote on forest science. ${ }^{1}$ As a forestry scholar, Carlowitz argued about the ongoing use of resources in long-term dimensions (across generations). ${ }^{2}$ He argued that timber would be "as important as daily bread" and that it should be "used with caution in a way, that there is a balance between timber growth and lumbering." For Malthus, sustainability was about maintaining the resource basis for continued production and consumption. ${ }^{3}$ Sustainable development is a relatively new concept, first developed in the 1980s. However, the origins of the concept can be traced back to the increased concern shown for the environment in the 1960s and 1970s. ${ }^{4}$ At the end of the last millennium, sustainable development became an overall guiding principle for human development to stress the need for the simultaneous achievement of development and environmental goals. ${ }^{5}$ Its success stems from underlying reflections on existential problems of mankind perceived at that time. These relate to increasing concern over the exploitation of natural resources and economic development at the expense of environmental quality. From this, one can understand that sustainability is meant to bridge the gulf between development and the environment.

The concept of sustainable development has been evolving for more than three decades. The 1972 United Nations Conference on the Human Environment in Stockholm, Sweden, contributed to this evolution by emphasizing that protection of the human environment is a crucial element in the development agenda. ${ }^{6}$ In the collective move towards

1 Carlowitz, H.C. Edler von SylviculturaOeconomica Meissen (1713) 18.

2 Marco Keiner, "History, Definition(s) and Models of Sustainable Development" (Eth Zuric, Research Collection, 2005) < https://www.researchcollection.ethz.ch/bitstream/handle/20.500.11850/53025/eth-2794301.pdf $>$ accessed on 20 September 2018.

3 Thomas Malthus, "An Essay on the Principle of Population" (Accompanying Historical Notes, 1978) < https:// www .le.ac.uk/users/dsgp1/COURSES/ ENVIRONS/malthus.pdf $>$ accessed on 10 January 2018. Malthus argued that population growth need to be checked to maintain the means of subsistence, arguing that population checks itself through misery, saying there is no need to check it through birth control. The reason why he wanted a reduction of population growth is that, large population will have large ecological footprint leading lead to the exhaustion of resources.

4 W. Alan Strong and Lesley A. Hemphill, Sustainable Development Policy Directory (Wiley, 2006) 422.

5 Marco (n 2).

6 P. Rogers, Jalal and Boydan, Introduction to Sustainable Development (Earthscan, 2012). 
the world we want in 2030, sustainable development has been elevated as the guiding principle. The policies of countries are, therefore, expected to be in harmony with this principle as the historic summit document opts to leave no one behind in its promotion. ${ }^{7}$

Africa in general and Sub-Saharan, in particular, has been plagued by civil wars, cross-border conflicts, social strife, and arms trafficking all of which affect developments negatively in the region. ${ }^{8}$ The Horn of Africa is one of the most complex and conflicted regions. Drought, famine, civil war and state failure have long been the defining features of the region. Each of the countries of the Horn suffers from protracted political strife, arising from local and national grievance, identity politics and regional inter-state rivalries. ${ }^{9}$ The Horn has also been a theatre of strategic power struggles for many years. Many countries have been competing to get control of the horn because of its strategic setup. The British Empire's demand to control the Red Sea, Egypt's attempt to control the Nile Waters, the Cold War confrontation in which each of the principal countries of the Horn switched sides at crucial junctures, and most recently the U.S. Administration's Global War on Terror could be raised as examples. In addition to the struggle of different countries to have control over the region, drought, famine, civil war and state failure have long been the defining features of this region, impacting the area negatively. Most of the problems have a dominant transnational/regional character. The social and economic problems in a country have intended as well as unintended spillover effects on neighbouring countries. ${ }^{10}$ Since long ago, there has been some policy

7 Transforming Our World: The 2030 Agenda for Sustainable Development. Un.Org A/Res/70/1. Under its preamble states that goals are integrated and indivisible and balance three dimensions of sustainable development: the economic, social and environmental. These goals and targets will simulate action for the next 15 years in the area of critical importance for human and the planet.

8 Catherine B. Keita and Solomane Kone , "Eastern Africa Regional Integration" (Strategy Paper 2011 - 2015, 2011).

9 Crisis in the Horn of Africa, http://Hornofafrica.Ssrc.Org accessed on 11/28/ 2017.

10 Mulugeta G. Hiwot, "Economic Integration As A Peace Building Strategy in the Horn of Africa With Particular Focus on Ethiopia and Its Four Neighbours"(2007) 1(1) AJ <http://www.ipss-addis.org/y-file-store/AfSol_Journal/ afsol_journal_vol_1_issue_1_mulugeta_gebrehiwot_berhe.pdf $>$ Accessed on 30 September 2018 . 
transformation in countries of the region, and now the major transformative agenda to tackle these problems is in action as the whole world is committed to ending poverty and bringing prosperity by 2030 .

Protection and improvement of the human environment are some of the major issues affecting the well-being and economic development of people throughout the world. Hence, these core expectations of people constitute part of the essential duties of all governments. The 18th-century, which was characterized by the industrial revolution, was a time that environmental protection required considerable attention. An overview of international conventions, policies and protocols on the environment, especially after the industrial revolution in the late 18th-century, increased the clamour for environmental law by the international community. Hence, environmental law, as a distinct system, arose in the 1960s in the major industrial economies. By then, it was already becoming clear that the cumulative negative environmental effects of human activities were going to be unsustainable in the long term. The environmental movement of the 1960s resulted in a massive legal response. ${ }^{11}$

On the international arena, the first official agreement regarding environmental protection was the Rasmar convention. ${ }^{12}$ This convention reached an agreement in 1971 to protect wetlands. Nowadays there are 168 signatories and about 208,674,247 hectares of land protected by Rasmar convention. ${ }^{13}$ At the 1972 Stockholm Conference, environmental protection became an agenda of discussion, ${ }^{14}$ and beyond that, it became an obligation for UN member states at the Stockholm

11 J William Futrell, "Environmental Ethics, Legal Ethics and Codes of Professional Responsibility" (27 Loy. L. A. L. Rev. 825,1994) <http://Digitalcommons. Lmu.Edu/Llr/Vol27/Iss3/5> accessed 20 August 2018.

12 This Convention provides the frame work for national action and international cooperation for the consecration and wise use of wetlands and their recourses as a contribution towards achieving global sustainable development. At present, 1459 wetland sites are designated for inclusion in the Rasmar list of wetlands of international importance.

13 Contracting Parties to Rasmar Convention on Wetlands, <http:// Archive.Ramsar.Org/Cda/En/Ramsar-About-Parties-Parties/Main/Ramsar/136-123\%5E23808_4000_0_> accessed on 10 October 2017.

14 Mulugeta Getu,"Defiance of Environmental Governance: Environmental Impact Assessment in Ethiopian Floriculture Industry" (2013) 4(4) EJERM $<$ http:// www.e3journals.org/cms/articles/1376567319_Getu.pdf $>$ accessed on 3 January 2018. 
Convention to conduct environmental impact assessment before starting any activity that affected the environment. ${ }^{15}$

The United States was one of the first countries where the "environment movement" took root. The movement started in the 1960s, resulting in the promulgation of National Environmental Policy Act by the Congress in $1969 .{ }^{16}$ Subsequently, an institution that works on environmental protection was established in the USA by $1970 .{ }^{17}$ The country also made Environmental Impact Assessment (EIA) mandatory for any development activity, as a prerequisite on proposed projects. ${ }^{18}$

Environmental protection not only caught the attention of countries but also different financial institutions. For instance, the World Bank issued a set of guidelines that mandate World Bank-funded projects to conduct EIA before their commencement. This is to ensure that developmental initiatives and activities place proper values on the environment thus making the initiatives sustainable. Other countries that take loans from the World Bank are required to also follow the same regulation by conducting EIAs just as the projects financed by the Bank itself. ${ }^{19}$ The awareness of EIA on the international arena and among developed countries, including the influence of financial institutions, led developing countries to enact EIA laws to protect the environment too and strive for sustainable development. Generally, as urban expansion, investment activities and industrial developments spread, countries have tended to devote more attention to environmental protection. For instance, the ambitious and transformative Sustainable Development Goals (SDGs) with 17 intertwined goals and 169 targets also offer a guiding principle that countries are expected to key into. It is now two years since the SDGs came into effect as guiding principles of governments to run till 2030. This presupposes introducing new environment-related policies and

15 Ibid 220-221.

16 Environmental Protection Agency (EPA), <http://www.Referencefor business.Com/Encyclopedia/Ent-Fac/ Environmental-Protection-AgencyEPA.Html > Accessed on 26 January 2017.

17 Alan Strong et.al (n 4).

18 Tesfaye Abate, "Environmental Impact Assessment and Monitoring under Ethiopian Law" (2012) 1(1) HLR < file://C:/Users/vostro\%2015/Downloads/ 98572-258681-1-PB.pdf $>$ accessed on 5 January 2018.

19 Ibid 103. 
laws or reviewing the existing ones, especially in the developing world.

Ethiopia has been hailed for its decade-long, successive doubledigit economic growth. ${ }^{20}$ It is called save as to the reality because mere economic development cannot really be meaningful unless it is sustainable. Conscious of this fact, therefore, Ethiopia has also given attention to introducing new environment-related laws and reviewing the existing ones in the past two decades. However, the place of sustainable development in these laws has not yet been properly assessed two years into the implementation of the SDGs. This article assesses Ethiopian environmental laws against the sustainable development objective to ensure the conformity of environmental laws with the SDGs, and to promote the SDGs to make the development meaningful.

The article analyses the place of sustainable development under the FDRE Constitution and the other three environmental laws (Environmental Impact Assessment Proclamation No. 299/2002, Environmental Pollution Control Proclamation No. 300/2002 and Solid Waste Management Proclamation No. 513/2007) with a view to determining the extent to which the laws conform to sustainable development initiatives. The analysis is anchored on the FDRE Constitution as it is the fundamental law of the land from which environment-related policies and laws evolve. The three proclamations are purposively selected as they give large coverage for environmental issues. However, this does not mean that there are no other laws which talk about the environment and sustainable development

Organizationally, the article is divided into five sections. Following this introductory section, section 2 explains the concept of sustainability in its strong and weak sense. Section 3 analyses the FDRE Constitution and the three proclamations in light of sustainable development. Section 4 deals with the challenges of promoting sustainable development, while section 5 draws conclusions and recommendations.

\section{CONCEPTUAL FRAMEWORK OF SUSTAINABLE DEVELOPMENT}

Despite considerable controversy on the concept of sustainable

20 Emelie César and Anders Ekbom, "Ethiopian Environmental and Climate Change" (Policy Brief, 2013)<https://pdfs.semanticscholar.org/6b8e/ Obd3fcab889e48b87c9422a504dbdeacc958.pdf> accessed on 28 July 2017. 
development, it has been endorsed by many governments in their legal systems. Owing to the ambiguity of the term "sustainable development", scholars have argued for and against various models of sustainability, starting from a light touch (weak form) to a more substantive and tougher test (strong form). ${ }^{21}$ The point of debate over these two forms of sustainability revolves around the degree to which "natural capital and human-made capital can be substituted for each other". ${ }^{22}$ The fundamental debate for a country regarding sustainable development is on choosing and adopting a sustainability model.

Weak sustainability postulates the full substitutability of natural capital. The strong conception, on the other hand, demonstrates that substitutability should be severely limited since some of the critical natural capital is irreplaceable by human-made capital, the former being important for human existence and well-being. ${ }^{23}$ This model allows the exploitation of natural capital as long as it is substituted by humanmade capital. It favours the use of natural capital (air, water, land and what is in and on land) and substitutes them with man-made capital, such as roads, housing, factories, machine etc. Proponents of weak sustainability model believe that future generations will be sufficiently compensated by the substitution or the wealth created using the natural capital. At the centre of weak sustainability model of sustainable development is optimism that "people will be able to find a solution to environmental problems that may arise by its usage (exploitation) thereby enhancing the stock of resources. ${ }^{24}$

Proponents of strong sustainability model argue that there are limits to which natural capital can be replaced or substituted by humanmade capital. Therefore, sustainability requires maintaining the level

21 Tsegai Berhane, "Interrogating the Economy-first Paradigm in 'Sustainable Development': Towards Integrating Development with the Ecosystem in Ethiopia" (2017) 11(1) $M L R<$ http://dx.doi.org/10.4314/mlr.v11i1.3> accessed on 20 August 2017.

22 John O'Neill, Markets Deliberation and Environment (New York: Routledge, 2007) 14.

23 J. Pelenc, J. Ballet and T. Dedeurwaerdere, "Weak Sustainability versus Strong Sustainability" (Brief for GSDR, 2015) < https://sustainabledevelopment. un.org/content/documents/6569122-Pelenc-Weak\%20Sustainability\% 20versus\% 20Strong\%20Sustainability.pdf> accessed on 15 August 2018.

24 C. Williams and A. Millington, "The Diverse and Contested Meanings of Sustainable Development" (2004) 170 (2) GJ < https://doi.org/10.1111/ j.0016-7398-2004.00111.x> accessed on 20 September 2018. 
of natural capital at or above the level judged to be critical. ${ }^{25}$ This model requires the use of natural capital in a way that enhances its value or replaces it with another form of natural capital ensuring nonreduction of the total stock of natural capital. If substitution is not possible, then do not use it! This is about the critical natural capital, which should be preserved absolutely. ${ }^{26}$

At the centre of strong sustainability is the earth's finiteness, which could result in no habitable future unless the demand side of the equation radically alters by rethinking our attitude towards nature as well as our view of economic progress and development. ${ }^{27}$ For advocates of stronger sustainability, "the weaker versions of sustainable development are much more about sustaining development rather than sustaining environment, nature, ecosystems or the earth's life support systems". ${ }^{28}$ In generally, strong sustainability sees environmental protection as a precondition for economic development and believes real economic development is impossible without environmental protection. For instance, research ${ }^{29}$ recommends the development of strong sustainability model urgently, since critical natural capital is a useful concept to help determine the degree of substitutability between natural capital and human-made capital in number or in space.

\section{ASSESSING THE CONTENTS OF THE FDRE CONSTITUTION AND THE THREE PROCLAMATIONS IN LIGHT OF SUSTAINABLE DEVELOPIMENT}

\subsection{Sustainable Development under the FDRE Constitution}

From its preamble through different provisions in the body of the FDRE Constitution, the term economic and social development is widely

25 John (n 22).

26 Dejene Girma, Law and Sustainable Development (Unpublished Power Point Material for Masters of Law in Law and Development, School of Law, Arsi University, 2016).

27 Williams \& Andrew (n 24) 102.

28 Ibid 104.

29 Lu Huang, "Exploring the Strengths and Limits of Strong and Weak Sustainability Indicators: A Case Study of the Assessment of China's Megacities with EF and GPI; Sustainability" (2018) 10: 349 JS <www.mdpi.com/journal/ sustainability > accessed on February 2018. 
used as an indication of commitment to development. Moreover, to make sure its strategy extends beyond development, the Constitution clearly provides for sustainable development. ${ }^{30}$ The 1995 Constitution included the principle of environmental rights, which is one of the human rights recognized in the Constitution. Environmental rights enshrined in the Constitution are the rights to a clean and healthy environment. ${ }^{31}$ The protection of the environment is made the duty of all according to this supreme law. The Constitution imposes a duty to protect the environment on government and citizens of the country. ${ }^{32}$ Just like new development compact (SDGs), the Constitution is inclusive of environmental protection. As a pillar of sustainable development in relation to environmental protection, the FDRE Constitution seems to be harmonious with the SDGs. There are bundles of provisions that deal with pillars of sustainable development in the Constitution, ${ }^{33}$ and even the word sustainable development is clearly used in the Constitution. In general, sustainable development is unequivocally recognized under the FDRE Constitution.

Furthermore, in reading the different provisions of the Constitution, one can understand that it aims to promote a strong sustainability model. This could be inferred from a reading of the environmental objective, which is meant to be implemented concomitantly with the

30 The Federal Democratic Republic of Ethiopia (FDRE Constitution) Proclamation No. 1/1995 s 43 (1). The provision read as follows; the peoples of ethiopia as a whole, and each nation, nationality and people in Ethiopia in particular have the right to improved living standards and to sustainable development. From this it could be understood that the Ethiopia as country and individual has the right to development which is sustainable one.

31 FDRE Constitution art 44 (1).

32 FDRE Constitution art 92 (4).

33 For instance, Article 41 of FDRE Constitution deals with economic, social and cultural right; whereby every Ethiopian has the right to engage freely in economic activity and to pursue a livelihood of his choice. Everyone has the right to equal access to public funded social services and government has obligation to provide social services. Article 89 imposes the responsibility on government to formulate policies that will benefit the whole nation of the from its natural resources. Environmental dimensions of sustainable development are dealt with under the provisions of section 44 and 92 of the Constitution. The social aspects of sustainable development are explained from the preamble through entire body of the Constitution such as under Article 41 (socio-cultural right), formulation of policies that enhance social development (Art 51(2), $52(2 \mathrm{c}), 77(10), 90$ to provide all Ethiopian nationals access to different social services like health, education, clean water, housing, food and social security. 
economic development programme. The Constitution demands that every development activity from its design through its implementation does no damage the environment. Demanding development without damaging the environment promotes the strong sustainability model which conforms to the requirement to use natural capital in a way that enhances its value or replaces it with another form of natural capital such that its total stock of natural capital is not reduced.

The FDRE Constitution appears to favour the social and environmental pillars of sustainable development. The Constitution gives greater value to the environmental and social pillars, since a higher percentage of Ethiopians lives in rural areas where their livelihood depends on agriculture. To impact an agrarian society, the focus has to be on environmental protection. Moreover, even as of today the Ethiopian economy depends on agriculture. To increase agricultural production, especially where it is dependent on natural rainfall unless protection of the environment is given prior attention, the disaster of climate change will be imminent. This possible justification explains why the FDRE Constitution places higher value on the social and environmental pillars of sustainable development.

\subsection{Sustainable Development under Environmental Impact Assessment Proclamation}

The Environmental Impact Assessment process, which originated in the United States in the late 1960s, has been adopted extensively in the rest of the world. ${ }^{34}$ EIA arose in response to pollution and the unnecessary degradation of natural resources caused by rapid and unsustainable industrialization, agricultural development, and technological progress. ${ }^{35}$ In Ethiopia, by constitutional principle and environmental policy, an independent law was promulgated in 2002 to integrate environmental issues into the decision-making process. It stipulates that EIA must be conducted for the protection of the environment prior to implementation or making a decision on development programme, thereby integrating environmental issues in development endeavour to promote sustainable development.

34 Jennifer C. Li, "Environmental Impact Assessments in Developing Countries: An Opportunity for Greater Environmental Security?" (Working paper 4, 2008) 5.

35 Mellese Damtie and Mesfine Bayou, "Overview of Environmental Impact Assessment in Ethiopia: Gaps and Challenges" (MELCA Mahiber, 2008) 2. 
EIA aims to identify and evaluate in advance any effect, be it positive or negative, which results from the implementation of a proposed project or public instrument. The purpose of EIA is to make sure economic development projects pay attention to environmental matters. The term sustainable development is clearly used in the proclamation. ${ }^{36}$ Therefore, one can easily understand that EIA intends to promote sustainable development.

The body of the proclamation contains many provisions that promote sustainable development. For instance, engagement of the public in decision making promotes the social aspect of sustainable development, and the precautionary principle guides environmental protection since there could be pros and cons of the project. In decisions on proposed projects where the impact study shows positive and negative environmental consequences, especially where it is only slightly or arguably beneficial on balance, the deciding authority is to prioritize a negative impact and refuse the continuation of such proposals. ${ }^{37}$ The proclamation tried to categorize projects into two - those ones required to conduct an impact assessment and others, leaving details of categories to be made by subsidiary legislation, that is, regulation to be enacted.

As in the FDRE Constitution, the term sustainable development directly used in environmental impact assessment. The very purpose of the proclamation is to integrate economy and ecology in promoting sustainable development. ${ }^{38}$ The weak sustainability model is used in the proclamation. This could be inferred from reading the provisions of the proclamation that seem to promote sustainable development. EIA proclamation allows the use of the natural resource to the extent it does not negate environmental and social values, which could be equated with weak sustainability model of sustainable development. The provision that deals with precautionary principle suggests that that environmental pillar receives more attention, but this is not exactly

36 On the preamble of Environmental Impact Assessment Proclamation No. 299/ 2002 , it is clearly stated what the proclamation is designed for; which is assessment of possible impacts on the environment prior to the approval of a public instrument. It provides an effective means of harmonizing and integrating environmental, economic, cultural and social considerations into a decision making process in a manner that promotes sustainable development.

37 Environmental Impact Assessment (EIA Proclamation) No. 299/2002 s 4(2).

38 EIA Proclamation preamble par 2. 
the case. Even in the preamble of the proclamation as contained in the third paragraph, environmental impact assessment is used as a means to bring about social and economic development. ${ }^{39}$ Thus, it could be said EIA proclamation did not prioritize any pillar over the other.

\subsection{Sustainable Development under Environmental Pollution Control Proclamation}

According to the World Health Organization, globally, one-quarter of all deaths and one-third of all child deaths can be attributed to environmental conditions. Ethiopia is one among countries with the highest number of deaths caused by pollution. ${ }^{40}$ The highest death toll due to pollution is recorded in Asia, and 19.1 per cent of deaths recorded in Ethiopia are pollution related. ${ }^{41}$ Over the past decade the world has woken up to the fast depleting non-renewable resources, loss of biodiversity, land degradation, increasing air pollution, ozone depletion, fast disappearing glaciers, polluted fresh water sources, sea erosion of land, nuclear waste, electronic waste, increasing deforestation, unchecked/unplanned development, and more large-scale, sudden onset disasters. ${ }^{42}$ From this, one can understand that it is urgent for countries to pay attention to their activities to avoid pollution. Rio principle 16 recognizes pollution effect and includes a polluter-pay principle. Accordingly, national authorities are required to promote the internalization of environmental costs and the use of economic instruments, using the polluter pay approach. The principle demands one who caused environmental damage through pollution should bear the cost of pollution. ${ }^{43}$

39 Under paragraph 3 of Environmental Impact Assessment Proclamation No. 299/2002 preamble, the implementation of the environmental rights and objectives enshrined in the Constitution would be fostered by the prediction and management of likely adverse environmental impacts, and the maximization of their socioeconomic benefits. This envisages promoting the environment and, at the same time, developing socio-economic matters.

40 Countries with the highest pollution deaths, mortality rates, https://phys.org/ news/2017-10-countries-highest-pollution-deaths-mortality.html accessed on $11 / 27 / 2017$.

41 Katy Daigle, "Environmental Pollution from filthy air to contaminated water" (Physorg, 20 October 2017) 3.

42 Ahmadabad, "Sustainable Development: An Introduction, internship series Centre for environmental education" (2007) 1 OAAP < http://www. sciepub.com/reference/41425> accessed on March 2018.

43 UNDP, Triple win for sustainable development (2012) 6. 
Cognizant of pollution problems, Ethiopia has enacted Environmental Pollution Control proclamation in 2002 intending to avoid pollution to any extent possible; and at least minimize pollution so that development endeavours may be productive. In the preamble of pollution control proclamation, paying attention to environmental harm ensures the progress of economic and social development endeavours. ${ }^{44}$ This means that activity done for economic development should promote sustainable development. Unlike the previous two laws analysed, i.e. FDRE Constitution and EIA proclamation, the term "sustainable development" is not used unequivocally. However, from a reading of the preamble and many other provisions of the Environmental Pollution Control proclamation, one can conclude sustainable development is envisaged in the proclamation and the development model. For instance, Article 5(1) of the proclamation assigns urban administration the duty of managing wastes. This, in turn, makes the city resilient and brings about integrated development and economic development without negative effect on the environment and social values (sustainable development). Any person engaged in the activity that likely causes pollution is required to take any appropriate measure that may avoid or reduce environmental danger and, when feasible, apply methods for the recycling of waste. ${ }^{45}$ Obviously, investment activities are those which most likely cause pollution. Therefore, those engaged in such activities are obliged by the proclamation not to pollute and to clean up the polluted environment in the spirit of the polluter pay principle, pursuant to Article 3(4).

The proclamation promotes weak sustainability model, it could be concluded since the proclamation intends to avoid pollution while using natural resources to bring development. The proclamation seems to promote sustainable development without inclining to any of the

44 According to Environmental Pollution Control Proclamation No. 300/2002, some social and economic development endeavours may inflict environmental damage that could make the endeavours counter-productive. Therefore, the proclamation want managing or controlling pollution without which development endeavour would be backfiring. Unless pollution is managed in the way that does not affect well-being of society, economic development might be less valuable since it will not bring sustainable development as envisaged both in constitution and environmental policy of the country.

45 Environmental Pollution Control Proclamation No. 300/2002, s 3(3). 
sustainable development pillars. The proclamation promotes the management of the negative environmental impact of development activities. It also underlines the protection of the environment in general, and the safeguard of human health and well-being, as well as maintaining the biota and the aesthetic value of nature in particular, putting its duty and responsibility on all. To that end, the proclamation aims to eliminate or, when not possible, mitigate pollution as an undesirable consequence of social and economic development activities. The proclamation prohibits everybody from causing pollution as it affects sustainable development, which is the current development model of the country.

\subsection{Sustainable Development under Solid West Management Proclamation}

Regardless of the context, managing solid waste is one of the biggest challenges of the urban areas of all sizes - from mega cities to the small towns and villages, which are home to the majority of humankind..$^{46}$ The management of solid waste is a growing problem in many urban areas in Africa today. ${ }^{47}$ Most cities in Africa with fast urban expansion are characterized by a lack of resources, institutional organization and the capacity to provide basic infrastructure, which in turn has caused increased problems concerning the management of solid waste. Moreover, lack of proper land use planning has resulted in the creation of informal settlements, with narrow streets that make it difficult for collection trucks to reach many areas of the cities. Assessments made regarding waste management in Ethiopia shows that waste management in Ethiopia affects water quality and health. ${ }^{48}$ Waste management in Ethiopia is regulated by solid waste management proclamation. According to the proclamation, public involvement in waste management is deemed critically important.

46 UN-HABITAT, Solid Waste Management in the World's Cities (Earthscan Ltd, Dunstan House, 14a St Cross Street, London EC1N 8XA, UK, 2010) 20.

47 Camilla Louise Bjerkli, "The Cycle of Plastic Waste: An Analysis on the Informal Plastic Recovery System in Addis Ababa, Ethiopia" (unpublished Master's Thesis NTNU Norwegian University of Science and Technology Department of Geography, 2005) 1.

48 Matthew Cheever, "Environmental Policy Review: Waste Management in Ethiopia" (2011). 
The proclamation did not use the term sustainable development plainly. However, a careful reading of its different provisions shows that it is intended to promote sustainable development. For instance, under the objective provision of the proclamation, managing waste is needed to ensure that economic activities do not adversely affect the environment. ${ }^{49}$ Like the pollution control proclamation, solid waste management proclamation aims at promoting sustainable development despite not mentioning the term specifically. This could be inferred from provisions of the proclamation that demand social and economic development and, at the same time, regulating wastes to ensure that development endeavours do not adversely affect the environment. ${ }^{50}$ Industries are required to dispose of their wastes properly. This means that development activities have to be comprehensive to balance ecology and economy. The sustainability model this proclamation seems to promote is most likely the weak form. It is possible to infer this as the proclamation wants to avoid adverse effects of development activity on the environment and society. To regulate waste management, the proclamation directs how disposal of waste should be done. If disposal of waste is done in a way that causes an adverse effect, it will compel the institution of civil and criminal charges. The proclamation promotes sustainable development without giving preferential treatment to one pillar over the other.

\section{CHALLENGES OF PROMOTING SUSTAINABLE DEVELOPMENT}

Nowadays, sustainable development is the social advancement model that every Member Country of the United Nations has adopted. It is a development strategy that can take the world to the desirable future. With the expiration of the MDGs which guided global development till

49 Article 3 of dry waste management proclamation which deals with the objective of the proclamation states that enhancing at all levels capacities to prevent the possible adverse impacts while creating economically and socially beneficial assets out of solid waste. In a number of provisions in the proclamation disposal of waste has to be in environmentally sound way.

50 The preamble, Article 3, 10 of solid waste management proclamation seems to promote economic endeavour without adversely affecting the environment through effective solid waste management; therefore it is possible to say the proclamation aims at promoting sustainable development. 
2015, the SDGs have been adopted as a more comprehensive and sustainable approach to the development of nations. To keep the development of nations on a growth path, the world has committed to 17 integrated SDGs with its 169 targets. This ambitious and transformative agenda has a lifespan of fifteen years, terminating in 2030. Within this time period, however, it provides an unheralded opportunity to address the persistent challenges facing the world, including poverty, growing inequalities, and environmental degradation. Through it, the world leaders have committed to addressing economic, social and environmental issues to promote sustainable development. ${ }^{51}$ It is barely two years now since the SDGs came into force to guide actions of governments for the next fifteen years. The fifteen-year-long journey offers ample time for real changes to be made to people's wellbeing across the world, yet it must be understood that the needs of the vast majority of the people demand urgency. As the way forward to realizing sustainable development, therefore, countries have enacted laws and reformed their policies to achieve proper implementation. However, the existing legal frameworks designed to bring about sustainable development may not be sufficient to achieve the desired result. In Ethiopia, as shown in the analysis of its laws, one can understand the existence of an enabling environment to promote sustainable development in spite of its recent implementation stage. Several factors have slowed the progress and contributed to holding back sustainable development from its fullest realization. Some of the challenges are discussed next.

\subsection{Weak Political Commitment}

Among other things, lack of political commitment to implement laws meant to promote sustainable development effectively is to blame. ${ }^{52}$ Mesfin and Mellesie argued that the Ethiopian government is highly involved in projects that enhance economic activities aimed at alleviating poverty as soon as possible even when these projects adversely affect the environment and fail to fully implement the EIA law. This, however, creates other problems by systematically inclining towards one pillar of sustainable development which, in fact, is an

51 Partnership for Action on Green Economy, Integrated Planning \& Sustainable Development: Challenges and Opportunities (Synthesis Report, PAGE, 2016) 1.

52 Damtie and Bayou (n 35) 52. 
obstacle to genuine sustainable development. This could be understood from weak public participation in decision making of investment project. For instance, the FDRE Constitution as well as EIA proclamation demands public participation on any development projects, especially one that directly or indirectly affects the interest of the surrounding societies. ${ }^{53}$ The practice of involving the public to participate in decision making is very limited or almost nil as documented in the literature. ${ }^{54}$

The EIA proclamation provides two stages of public participation in project decision making. During the first stage, proponents of the development project can be seen conducting EIA, while the second stage involves a review process of the impact study. This, however, is not implemented genuinely and is very weak. Some proponents of the development project list names of a few individuals together with their signatures or thumbprints as those who have participated in the environmental impact study. Mellese Damtie and Mesfin Bayou doubt the genuineness of environmental impact study examining some documents of the environmental impact study. Reviewers also do not go so far to make sure that it is conducted genuinely and whether the said participants are consulted. This could be observed even from the

531 For detail, see provisions of Article 43(2) of FDRE Constitution and Article 15 (2) of EIA proclamation. Article 43(2) reads as follow "Nationals have the right to participate in national development and, in particular, to be consulted with respect to policies and projects affecting their community". EIA proclamation No. 299/2002 reads: "The Authority or the relevant regional environmental agency shall ensure that the comments made by the public and in particular by the communities likely to be affected by the implementation of a project are incorporated into the environmental impact study report as well as in its evaluation".

54 For instance, an article published on Jimma University Law Journal, Volume 4, No 1, by Dr Dejene Girma Janka, entitled as "Participation of Stakeholders in Environmental Impact Assessment Process in Ethiopia" 50; Dejene argued that the culture of involving people in decision making is not known in many countries and regions, including our Ethiopia. He added that public participation is perceived as a threat to authority and is viewed defensively by many government agencies and project proponents. "We know better approaches" is thus mostly used in decision making and, therefore, government does not accept that stakeholders' involvement can improve the quality of development initiatives. Yenehun Birlie Mamo on his article published on Jimma University Journal of Law Vol. 4 No. 1 (2012) entitled "Law for the Future: the Legal and Policy Foundation for IGE", the author analysed policies, strategies and different laws, including the FDRE Constitution, and concluded that on the legal acceptance of intergenerational equity legally and politically. However, the intergenerational equity accepted in principle is challenged due to poor public participation. 
time allowed for reviewing environmental impact study. Reviewers are expected to scrutinize the impact study within 15 working days. ${ }^{55}$ It is very difficult to examine even a single environmental impact study within 15 working days as it includes cross verifications and site visits. Oromia Regional State EIA proclamation, Proclamation No. 176/2012, gives 10 days to review environmental impact study. ${ }^{56}$ This timeframe is simply given without adequate consideration for the volume of documentation generated by an impact study.

Moreover, reviewers fear to go further investigating the reality of the impact study as they will be called anti-development agents by the government. An interview with one of environmental impact study review officers at Shashamanne woreda revealed such problem. Moreover, the environmental impact study of "Afri-flower plc flower farm project" shows brazen lack of commitment as the people said to have participated in the environmental impact study were not inhabitants of the surrounding society while, in fact, the project had already been approved and commenced operations. ${ }^{57}$ This shows weak political commitment to implementing even the existing laws to ensure sustainable development in the country.

\subsection{Prioritizing One Pillar of Development over the Other: The Economy-First Paradigm}

Sustainable development can only be realized when the three pillars of development namely, economic, environment and social aspect are given equal priority. In Ethiopia, when we compare the government's commitment to promoting investment and other development projects with its commitment to environmental protection, the imbalance is clear. ${ }^{58}$ There is indisputable evidence of a weak political will to protect

55 Environmental Impact Assessment Proclamation No. 299/2002 s 9(2).

56 Oromia National Regional State Environmental Impact Assessment Proclamation No. 176/2012 s 11(2).

57 Azene Endalamaw and Wakgari Dulume, "Environmental Impact Assessment: the Law and the Practice, Oromiya Justice Organs Professionals Training and Legal Research Institute" (Unpublished research paper, 2008) 60.

58 For instance, if we observe the Growth and Transformation Plans (GTPs I \& GTPII) which is the long-term plan of the country, it seems to incline to economic growth. Achieving broad based, accelerated and sustained economic growth in order to eradicate poverty and became middle income country by 2023 was the objective of GTPI. Even though one cannot say environmental protection was 
the environment, including the EIA process. ${ }^{59}$ Jonathan MCKEE, a European Commission delegate to Ethiopia alongside other researchers on the Ethiopian Environmental Profile, concluded that a number of policies meant to guide and speed up development, some of which included environmental considerations, are mostly weak in that regard. ${ }^{60} \mathrm{He}$ added that despite awareness creation and conservation strategy of Ethiopia on environmental issues which contributed to key achievements on environmental policies and institutions, the environment still remains extremely marginalized both theoretically and practically, in the main components of the government's poverty reduction programme. In the development strategy of Ethiopia, known as Agricultural Development Lead Industrialization (ADLI), a development strategy for rural development, food security and overall poverty reduction, very little is done to integrate environmental issues within the key priorities. Even if the second growth and transformation plan seems to have accommodated environmental issues better than the first growth and transformation plan, environmental issues still lack the protection they deserve as compared to the economy. ${ }^{61}$

Before its elevation to the status of a Ministry, the Environmental Protection Authority (EPA) conducted a survey in 2005 which indicated that 118 industrial establishments in Addis Ababa were discharging waste containing hazardous pollutants into all-purpose streams, water bodies and the air. Different economic projects in Oromia regional state, for instance, affect the well-being of society in their bid to achieve economic development. In recent times, different Oromo activists have been campaigning against the renewal of Lagadambi gold mining ${ }^{62}$ license for causing social and environmental problems for its host

disregarded in this long-term plan, environmental protection wasn't stipulated in the document in an unequivocal manner and as a major objective, which shows priority of economic growth over environmental protection. This however could be hindrance to sustainable development.

59 Damtie and Bayou (n 35) 60.

60 Jonathan MCKEE, "Ethiopia Country Environmental Profile" (2007).

61 FDRE Ministry of Finance and Economic Development, "Federal Democratic Republic of Ethiopia Growth and Transformation Plan 2010/11-2014/15" (2010) 120.

62 OBN report on tantalum producing company locate in Guji Zone of Oromia National Regional State shows the company is damaging environment and threatening life of the surrounding societies; and renewal of Lagadambi gold mining license has resulted in unrest which is a recent phenomenon. For instance, \#DejeneGirmaJanka how specialized on environment has been advocating 
community. Other research works have shown that environmental agencies are threatened not to take any measure on environmentally unsound investments other than to write simple warning notices to such projects. ${ }^{63}$ This development shows the bias toward economic development at the expense of the environment. It also shows what challenge this trend poses to the achievement of sustainable development in Ethiopia in the fullest sense.

\subsection{Lack of Synergy}

Achievement of sustainable development, particularly the SDGs, is only possible with synergy at international and national levels. That is why the 2030 agenda made revitalizing partnership a cornerstone for the realization of SDGs. Achievement of the global commitments related to the SDGs is not very encouraging as a number of commitments on trade, aid, investment, and financing for the development of the Least Developed Countries (LDCs) have not been significantly met. ${ }^{64}$ For instance, in the 2030 agenda, developed countries have committed to making Official Development Assistance (ODA) available to reduce financial constraints of LDCs (Target 2 of goal 17). This commitment is made to create synergy at the international level and help LDCs in their shortage of resource to bring prosperity by 2030. Accordingly, developed countries have made a commitment to assist 0.7 per cent of their GNI, which in most cases delivered in less than the amount of commitment. ${ }^{65}$ For instance, ODA commitment is raised by 6.7 per cent compared to the figures for 2014 in 2015. Despite the increases, net ODA at 0.3 per cent of donor GNI, fell short of the commitment by many donors to achieve the target of 0.7 per cent of ODA/GNI. ${ }^{66} \mathrm{Had}$

protection of the environment and society on his social media, particularly Facebook; since 2018/05/03 until the time license of the said company was suspended. He particularly raised legal issues and demanded the suspension or revocation of the license which, in fact, was suspended later on.

63 For instance interview with Aschaalew Simee, environmental impact assessment review expert at Bishoftu city environmental protection office oscillates from lack of commitment to disinterest to anger at investors and, finally, preference to keep silent event when environment is in danger.

64 United Nations, the Sustainable Development Goals (UN Report, 2017) 5.

65 OECD, "Official Development Assistance Data" (5 August 2016) http:// www.un.org/esa/ffd/ ffd-follow-up/inter-agency-task-force.html\%5Cnhttps:/ /data.oecd.org/oda/net-oda.htm accessed on 9 August 2018.

66 Ibid 10. 
there been synergy and high political commitment, delivery of promises would not have decline monetarily. Countries promise to unite against certain global problems at different forums but rarely perform promises made because of different conflicting interests. Climate change (Goal 13 ) is a classic example.

In Ethiopia, a cross-cutting problem of synergy is revealed as environmental agencies, particularly federal and regional environmental agencies, have been facing poor communication with one another and the other relevant bodies. ${ }^{67}$ Environmental protection through EIA requires coordination and cooperation. For instance, the Federal Environmental Protection Authority (FEPA) can provide the Regional Environmental Agencies (REAs) with scientific and technical support to help them build their capacity. REAs can also report to FEPA on their environmental performances. Further, REAs can refer the EIAs of trans-regional projects to FEPA because reviewing such EIAs falls under the jurisdiction of FEPA. ${ }^{68}$

Investigations, however, show that communication or synergy between these environmental agencies is shallow. Another study conducted by Oromia Justice Sector Professionals Training and Legal Research Institute on environmental impact assessment shows the same result. ${ }^{69}$ For instance, one of these institutions can give a certain land for investment while another institution objects to the use of such land for the said investment. In Oromia state Matu woreda, a special place known as "Algee Goosu" investment office arranged 7000 hectares of land for investment and claimed to have investment license while one of Oromia state public enterprise called "Dhaabbata Bosonaa fi Bineensota Bosonaa Oromiyaa" objected to the perfecting of the land document and the investment, saying it is a forest land. The license was later suspended because of the conflict. These examples show that less attention is paid to the environmental pillar of sustainable development compared to the social and economic pillars. This reality would make it difficult to achieve sustainable development.

\subsection{Gaps in the Laws}

The legal gaps for sustainable development exist mainly in relation to

67 Dejene Girma Janka, "Environmental Impact Assessment In Ethiopia: Laws and Practices" [2012] TA 145.

68 Ibid 146-147.

69 Azene and Wakgari (n 58) 85. 
EIA law. The EIA Proclamation attaches great importance to procedure. However, two legal gaps can be mentioned in relation to the proclamation. First, the proclamation is not supported by subsidiary laws. As Dejene indicated, the proclamation contains so many general and vague stipulations, which are difficult to enforce without subsidiary laws. ${ }^{70}$ Nevertheless, there are few subsidiary instruments issued to enforce the EIA Proclamation up to date. For example, the 2003 EIA Procedural Guidelines and the 2008 EIA Directive, which contain the list of projects subject to EIA, are the only ones. Even so, the directive has various defects. ${ }^{71}$ One of such defects is that it contains only few projects which are subject to EIA. ${ }^{72}$ In short, the Council of Ministers has not issued EIA regulation, which is necessary for the effective implementation of the Proclamation. Similarly, the Federal Environmental Protection Agency has not yet issued a comprehensive directive to implement the Proclamation. In a federation such as Ethiopia, a plurality of laws and institutions are common. Accordingly, Oromia state, for instance, enacted EIA proclamation in 2012. The EIA proclamation of Oromia (Proclamation No. 176/2012 under Article 7) refers to regulation to be enacted to determine projects that demand environmental impact assessment. The regulation, however, has not

70 Dejene Girma, "The Chance to Improve the System of EIA in Ethiopia: A Look at the New Investment Proclamation" (2014) 3(1) OLJ < www.ajol > accessed on January 2018.

71 For instance, as cited by Dejene at footnote 32 on his article about improving EIA system challenges on projects has been revealed. These projects are mining explorations that are subject to Federal Government permit, dam and reservoir construction (dam height 15m or more, reservoir storage capacity 3 million m3 or more, or power generation capacity 10MW or more), irrigation development (irrigated area of 3000 ha or more), construction of roads (Design and Standard DS1, DS2, DS3) with a traffic flow of 1000 or more, railway construction, taking fish from lakes on a commercial scale, horticulture and floriculture development for expert, textile factory, tannery, sugar refinery, cement factory, tyre factory with production capacity of $15,000 \mathrm{~kg}$ /day or more, construction of urban and industrial waste disposal facility, paper factory, abattoir construction with slaughtering capacity of 10,000/year or more, hospital construction, basic chemicals and chemical products manufacturing factory, any project planned to be implemented in or near areas designated as protected, metallurgical factory with a daily production capacity of equal or more than $24,000 \mathrm{~kg}$, airport construction, installation for the storage of petroleum products with a capacity of 25,000 litters or more, condominium construction, establishment of industrial zone. More projects should be subjected to EIA.

72 Dejene (n 71) 146. 
been established, thus hindering the uniform application of impact assessment on similar projects. This shows the legal gaps created to affect effective implementation.

Secondly, mainstreaming EIA systems in sectoral laws create additional opportunity for its effective implementation. If sectoral laws require the use of EIA for actions that take place in their respective areas, the institutions in charge of overseeing their implementation will ensure that EIA is also used when required. ${ }^{73}$ This will, in turn, ensure the consideration of environmental values in the decision-making process to ultimately promote environmental protection. However, some sectoral laws have missed the opportunity. ${ }^{74}$ For example, it is possible for any land law to require the preparation of EIA before access is given to land for some projects. Wildlife protection laws could also require the preparation of EIA before permissions, e.g. to hunt in a particular place, can be granted to tourists. But, both laws fail to do that. In short, the Ethiopian EIA law, as it stands now, is inadequate to contribute maximally to sustainable development.

\subsection{Weak Institutional Capacity}

The problem of institutional capacity is best seen from two perspectives: consultants and the institutional accountability of the Environmental Protection Authority. To begin with, consultants are very important actors in the EIA process as they are the ones who prepare Environmental Impact Study Reports (EISR) on behalf of the applicant. ${ }^{75}$ Conducting EIA, by its very nature, is a multidisciplinary task. However, since there is no code of conduct governing how such a multidisciplinary task should be done, consultants risk being highly influenced by their clients. ${ }^{76}$ Besides this, the existing consultants are not well qualified to carry out EISR in an efficient manner. ${ }^{77}$

Regarding institutional accountability, the EPA is accountable to the Prime Minister. ${ }^{78}$ However, EPA, as a regulatory organ, is expected

73 Ibid 147.

74 It is also good to note that there are some sectoral laws which included the EIA system. The Mining Operations Proclamation No. 678/2010 and the new Investment Proclamation No. 769/2012 are cases in point.

75 Damtie and Bayou (n 35) 40.

75 Ibid 41.

77 Ibid 42.

78 Environmental Protection Agency Establishment Proclamation No. 295/ 2002 s $3(2)$. 
to regulate the activities carried out not only by private project owners but also the government. Yet, it is not organized in such a manner that it could effectively regulate the activities of government-owned projects. Most government offices are placed at a higher level than the EPA, and this prevents the EPA from regulating their activities. Regulatory organs need to have sufficient powers, or they will remain crippled. EPA can do nothing, at least at the moment, if some government offices want to disobey the EIA law.

\section{CONCLUSION}

The Post-2015 Agenda is an unprecedented development initiative that embodies universal aspirations for achieving a better, more just, equitable, peaceful and sustainable future. The achievement of the 2030 Agenda for sustainable development through the Sustainable Development Goals will require the participation of all stakeholders. The Ethiopian Constitution and environmental laws have been recognized as instruments to promote sustainable development.

The FDRE Constitution seems to promote strong sustainability model while the environmental laws promote the weak form. A legal framework for sustainable development exists in Ethiopian environmental laws with their lacunae. However, implementation is limited by the traditional deference to the economy at the expense of the environment. Weak political commitment to fully implement existing laws that are meant to promote sustainable development, prioritizing one pillar of development over the other, lack of synergy between institutions meant to promote sustainable development and weak institutional capacity as well as legal gaps are among challenges to the implementation of sustainable development, despite the existence of various laws meant to promote it in Ethiopia.

To address the challenges hindering the fullest implementation of sustainable development, the government has to pay equal attention to the pillars of development. The Ethiopian Constitution, as well as environmental laws, have incorporated sustainable development. Therefore, these laws deserve full implementation. Implementing institutions such as environmental agencies as well as investment authorities have to pay equal attention to environmental and social pillars as they do for the economic pillar of sustainable development. This means that the economy-first paradigm should be changed as the country is paying lip service values to other pillars of development 
other than the economy.

Moreover, the council of ministers at the federal level and regional administrative council have to enact subsidiary laws, i.e., both regulation and directives, that are necessary to fully implement the EIA Proclamation. Moreover, sectoral laws, at least the ones to be enacted or amended in the future, have to mainstream the EIA system. Genuine political commitment and public participation which result in the punishment of institutions that fail to fully implement laws are also necessary for sustainable development.

Regarding the foregoing, therefore, the Parliament and Caffe Oromia have to amend both the Federal and Oromia EIA proclamations particularly provisions dealing with the review of the environmental impact study. The time limit allowed for reviewers to finish inspecting the environment impact study should be based on the volume of work to be done on the report. Also, regarding the EIA, the demonstration of weak institutional capacity both by consultants and reviewers alike should be checked. The government has to work on strengthening reviewers of impact study as the main stakeholders of the EIA process through financing, capacity building and training. Also, a Code of conduct for EIA consultants has to be developed and adhered to. In this regard, guidelines which provide for the registration, accreditation and licensing of consultants who prepare the EISR must be produced and approved by the Environmental Council. Training should also be arranged to conduct EISR effectively and efficiently. 